\title{
Childhood Experiences of North Korean Refugees at the Intersection of Disability and Refugee Status
}

\author{
Yosung Song, Ph.D. \\ Assistant Professor, Department of Education \\ Moravian College, Bethlehem, PA \\ Justin Freedman, Ph.D \\ Assistant Professor, Department of Interdisciplinary and Inclusive Education \\ Rowan University, Glassboro, NJ
}

\begin{abstract}
The purpose of this paper is to examine the intersection of disability and refugee identity, as experienced by North Koreans during their childhood and adolescence. A Critical Disability Studies theoretical framework is used to examine the interplay of social and embodied aspects of disability within the conditions faced by North Korean refugees across multiple borders and contexts. Data include interviews with two teachers and eight young adults and students about their childhood experiences before, during, and after their journey to relocate in South Korea. The findings illuminate the violence that North Korean refugee children and adolescents experience, as well as the structural, political, economic, and cultural conditions that shape North Korean refugee children's access to rights, such as health care and education. Further, we highlight how identities, such as gender and ethnicity, affect the embodied experiences of North Korean refugee children.
\end{abstract}

Keywords: refugee, disability, social embodiment, critical disability studies 


\section{Introduction}

Several countries around the world have seen a sharp increase in the number of schoolage refugees ${ }^{i}$ and asylum-seekers. This trend is likely to continue, given current geo-political turmoil (UNHCR, 2018a; Martin \& Yankay, 2012). During relocation, many school-age refugees or asylum-seekers face conditions that deprive them of human rights, by being subject to human trafficking and/or child labor and being denied formal educational opportunities (DrydenPeterson, 2011). Once relocated in a new country, school-age refugees or asylum-seekers are often characterized as having experienced trauma, depression, and poverty, which causes adverse physical and emotional conditions, as well as difficulties in learning and language proficiency (Fazel, Reed, Panter-Brick, \& Stein, 2012; Graham, Minhas, \& Paxton, 2016).

According to United Nation's Convention on the Rights of the Child (UNCRC), a child is "every human being below the age of eighteen years unless under the law applicable to the child, majority is attained earlier" (UN General Assembly, 1989, Article I). The UNCRC further states that a child "needs special safeguards and care, including appropriate legal protection, before as well as after birth" (Article I). In the case of North Korea, many refugee children and adolescents face vulnerable conditions before, during, and after their relocation. Since a nationwide famine struck the dictatorship of North Korea in the 1990s, a growing number of North Koreans have escaped from their homeland and relocated to South Korea in search of food stability (Ministry of Unification, 2018). The journey of escaping from North Korea includes a series of illegal and dangerous border crossings. Although North Korea and South Korea border each other, it is almost impossible to cross the border between the two countries due to heavy military surveillance. Therefore, many North Koreans attempt to leave North Korea through its northern border with China (KINU, 2018; Lee, 2006).

China has become a particularly unsafe place for North Korean refugees. The Chinese government considers North Korean refugees as illegal economic migrants and maintains the position of not qualifying North Koreans for protection under the 1951 United Nations Convention Relating to the Status of Refugees (Aldrich, 2011). Since data on the relocation of North Koreans to South Korea were first collected in 1948, 72\% of the 33,022 North Korean refugees who have entered South Korea are women. Among the total number of North Koreans, 4,988 (approximately 15\%) are those between 0 to 19 years of age (Ministry of Unification, 
2019). Women may seek to relocate in greater numbers because of North Korea's oppressive social and cultural practices towards women (Human Rights Watch, 2018) and its paternalistic culture that requires men's job attendance more than women's (KINU, 2018). During their relocation journey in China, many female North Koreans, including adolescents, are sold to work in the sex industry or become a caregiver, or a wife, to men in rural areas, including those with low socioeconomic status and disabilities who are unlikely to find a Chinese wife (Choe, 2018; Hwang, 2019; United States Department of State, 2018).

If an individual's North Korean refugee status is revealed to the Chinese authorities, they are deported to their homeland where they face harsh repercussions. To avoid forced repatriation, North Koreans often endure inhumane treatments in China and become vulnerable to adverse physical or psychological conditions, in addition to interrupted formal education (KINU, 2019). Some North Koreans receiving financial support from their family members who relocated to South Korea earlier may take a comparatively safe journey by hiring smugglers in China, and other countries. As the number of North Koreans entering South Korea has increased, many North Koreans send money to their remaining family members in North Korea using brokers in China who work as messengers between the two parties in South and North Korea (Harlan, 2012; Lankov, 2011). However, those who cannot afford to hire smugglers often spend several months or years in China while hiding their status as North Koreans, risking forced repatriation, imprisonment, torture, and trafficking, until they can manage to relocate to South Korea (KINU, 2017; KINU, 2018).

Once North Korean refugees arrive in South Korea and successfully complete an intensive background check, they receive South Korean citizenship as well as educational and social benefits, such as free housing and free tuition up to higher education (Ministry of Unification, 2018). However, North Koreans in South Korea experience marginalization as a result of a stigma attached to their identity as North Koreans. Demonstrating characteristics such as the use of a North Korean accent, thinner and shorter body figures than average South Koreans, and a lack of familiarity with South Korean culture, North Koreans are perceived as being deficient in cultural and economic competency in South Korean society (Choi, 2011; Yoo, 2008). Without cultural and social capital in South Korea, many North Koreans also face economic challenges, which result in higher unemployment rates (Ministry of Unification, 2019; OECD, 2019). 
In South Korean schools, North Korean students with refugee backgrounds encounter new cultural practices that stigmatize their culture and frames their differences as deficits (Jung, Jung, \& Yang, 2006). Many North Korean students with refugee backgrounds who attend mainstream schools in South Korea are often perceived as having learning delays or emotional and behavioral issues (Kim, 2010). The first author witnessed this first-hand as an elementary teacher in South Korea where several students from North Korea were enrolled. Teachers at the school often described these students as behaviorally "challenging" or academically "slow" or "behind." Facing the challenge of adjusting to a new culture and school system, many North Korean students drop out of South Korean mainstream schools. Others, including some of the participants in the study described in this paper, leave for alternative schools within South Korea that exclusively serve North Korean students with refugee backgrounds (KEDI, 2016; Schwartzman, 2009).

The purpose of this paper is to examine how the intersection of disability and refugee status is experienced by North Korean refugees during their childhood. Recognizing that refugee status is a political construct (Hacking, 1999) and that disability is both a socially constructed and embodied experience (Thomas, 2004), we utilize Critical Disability Studies as a theoretical framework of this study to examine how these identities intersect to affect the lives of children who traverse multiple borders and educational contexts. We report findings of the violence that Korean refugee children and adolescents experience during their journey, as well as the structural, political, economic, and cultural conditions that shape North Korean refugee children's access to rights such as health care and education after relocating to South Korea.

\section{Theoretical Framework: Critical Disability Studies}

Our approach to examining the intersection of disability and refugee identity is guided by Critical Disability Studies (CDS). CDS is a sub-discipline of the larger field of Disability Studies that emphasizes the material consequences when theorizing disability (Goodley, 2013). Materialism - largely influenced by Marxism - is a critical framework that considers the circumstances in which bodies exist. Material theories of disability consider how individuals and groups are systematically excluded from economic and political participation when they cannot lay claim to privileged identities such as able-bodiedness and Whiteness (Annamma, Connor, \& Ferri, 2016). Using a materialist approach, CDS scholars have criticized how transnational 
capitalism has excluded certain bodies from economic and political participation, and forced individuals to embody disabilities through wars, political conflicts, and an imbalance of economic power (Erevelles, 2011; Goodley, 2013). The materialist emphasis of CDS also examines how disability is discursively constructed in ways that marginalize individuals and groups that are constituted as disabled (Meekosha \& Shuttleworth, 2009).

The focus on material conditions within CDS brings increased attention to the embodied experience of disability. Embodied aspects of disability have previously been emphasized within Feminist Disability Studies, which theorize how normative ideas about bodies exist in relation to their social and material environments (Garland-Thomson, 2005). Further, the emphasis on embodied aspects of disability is a critical response to the disharmony between impairment and disability in a social model of disability. A social model of disability has politicized disability, yet often portrays impaired bodies as apolitical realities (Erevelles, 2011; Shakespeare, 2014). Thus, the absence of impaired bodies in the social model of disability obscures both how individuals become impaired and their embodied experience of impairment. The emerging field of Mad Studies has further contributed to theorizing the embodied experience of disability (e.g., pain) by asserting the mind as being interconnected with the body. Theorizing the singular "bodymind" calls attention to how "mental and physical processes not only affect each other but also give rise to each other," by acting as one (Price, 2015, p. 2).

Theorizing disability from the perspective of the global South has further illuminated how CDS aligns with both social and embodied elements of disability. Connell (2011) discusses the "social embodiment" of disability, referring to "the collective, reflexive process that embroils bodies in social dynamics, and social dynamics in bodies" (p. 1370). For example, bodies become impaired in the first place through the influence of global power dynamics. Therefore, impairment is particularly visible in places where individuals are more vulnerable to natural disasters of the effects of transnational capitalism (Meekosha \& Shuttleworth, 2009). Perspectives of the global South reflect an inward critique of theories of disability, including the limitations of predominant theories of disability in the global North, such as disability as a form of social marginalization created by medicalized responses to disability. Consideration of the social dynamics of contexts in the global South demonstrate how it is the absence of such medical resources that disproportionately leads to impairment, social marginalization, and death (Pisani \& Grech, 2015; Soldatic \& Grech, 2014). 
Another important element of a CDS framework that we draw upon is an intersectional approach to theorizing disability. Intersectionality generally refers to attempts to theorize the social phenomenon of marginalization of minoritized individuals and groups through the consideration of multiple identities (Crenshaw, 1989). As Goodley (2013) describes, intersectionality involves analysis across sociocultural categories and forms of interpellation to ask how, for example, disability, gender, race, sexuality, and class constitute or contradict one another. For example, intersectional approaches to disability attempt to explain how multiple identity categories mediate who is considered abled or disabled (i.e., dis/abled) in specific social contexts (Annamma, Connor, \& Ferri, 2016). With these understandings of intersectionality, we approach our analysis of refugee and disability identity not as discrete or additional identities, but as mutually constituted; we aim to explain the consequences of how refugee and disability identity are both constructed and embodied within material circumstances. With its intersectional focus and multi-faceted approach to theorizing disability, a CDS framework is useful for examining the lives of refugee children and adolescents, such as North Korean refugee children who are positioned to experience physical impairments and psychological distress.

\section{Research methodology}

In this study, a qualitative research methodology was employed to examine experiences of North Koreans who spent their childhood as refugees. This study draws on data from two separate qualitative studies that were conducted between 2015 and 2017. The first study was conducted between 2015 and 2016 with members of United Korea (pseudonym), a South Korean-based non-government organization (NGO) established in 1997. United Korea has helped North Korean refugees in China to safely relocate to South Korea. The first author built a professional relationship with this local NGO, United Korea. Eleven young adults (ages 20-26), North Korean refugees who were members of United Korea, participated in semi-structured interviews (Bogdan \& Biklen, 2007) about their experiences living in North Korean and relocating to South Korea via China.

The second study was conducted in 2017 at an alternative school in South Korea, Hankook School (pseudonym), serving North Korean students with refugee backgroundsii Hankook School is one of several schools that exclusively serve North Korean students with refugee backgrounds in South Korea. The school was founded through a collaborative effort by 
multiple Christian organizations. Further information about the school and organization is withheld to protect the safety and privacy of participants. In 2016, the first author developed a relationship with Hankook School. To build a rapport with members of the school community, the first author volunteered after school as a tutor of students at Hankook School. Data were collected via participant observations (e.g., classroom, school events, and daily interactions among teachers, students, and staff members), document collections (e.g., school newsletters, textbooks, school curricula, educational philosophy), and semi-structured interviews. Interview participants included nine teachers (including two school leaders) and seven students. Research methods and interview protocols for both studies were reviewed and approved by the Institutional Review Board at the authors' university.

This paper reports on selected data across the two studies described above. The data analyzed consist of interview data from nine participants - two young adult members of United Korea, and eight members of Hankook School (one school leader, one teacher, and six students). During interviews, participants were asked about their journey escaping from North Korea, challenges during and after their refugee journey, their experiences related to disability, and how they have adjusted to South Korean schooling and broader society. To ensure accuracy of interview data, the first author conducted follow-up interviews. Detailed participant information is included in Table 1. Data from the perspectives of these nine individuals were selected for analysis based on the theoretical lens of this paper - Critical Disability Studies. The selected data offer insight into the structural, political, economic, and cultural conditions of children and adolescents at the intersection of disability and refugee status. 
Table 1. Participant Information

\begin{tabular}{|c|c|c|c|c|}
\hline $\begin{array}{c}\text { Name } \\
\text { (Pseudonym) }\end{array}$ & Age & $\begin{array}{c}\text { Self-identified } \\
\text { Gender }\end{array}$ & $\begin{array}{c}\text { Time spent as a refugee } \& \\
\text { Corresponding Ages }\end{array}$ & Affiliation \\
\hline Eun & 21 & $\mathrm{~F}$ & $\begin{array}{c}2.5 \text { years } \\
(16-18)\end{array}$ & United Korea \\
\hline Shane & 23 & M & $\begin{array}{l}1.5 \text { years } \\
(14-15)\end{array}$ & United Korea \\
\hline $\mathrm{Kim}$ & 22 & $\mathrm{~F}$ & $\begin{array}{l}3 \text { years } \\
(15-17)\end{array}$ & Hankook School \\
\hline Jung & 19 & M & $\begin{array}{l}5 \text { years } \\
(9-14)\end{array}$ & Hankook School \\
\hline Moon & 22 & M & $\begin{array}{l}10 \text { years } \\
(11-21)\end{array}$ & Hankook School \\
\hline $\mathrm{Mi}$ & 23 & $\mathrm{~F}$ & $\begin{array}{l}4 \text { years } \\
(17-20)\end{array}$ & Hankook School \\
\hline Hyang & 17 & $\mathrm{~F}$ & $\begin{array}{l}6 \text { months } \\
(12-13)\end{array}$ & Hankook School \\
\hline Young & 21 & $\mathrm{~F}$ & $\begin{array}{l}6 \text { months } \\
\text { (14) }\end{array}$ & Hankook School \\
\hline $\begin{array}{c}\text { Ms. Yeon } \\
\text { (School leader) }\end{array}$ & $50 \mathrm{~s}$ & $\mathrm{~F}$ & $\mathrm{n} / \mathrm{a}$ & Hankook School \\
\hline $\begin{array}{l}\text { Mr. Song } \\
\text { (Teacher) }\end{array}$ & $40 s$ & M & $\mathrm{n} / \mathrm{a}$ & Hankook School \\
\hline
\end{tabular}

Participants were interviewed in their native Korean language. All the interviews were audio recorded and transcribed verbatim. Audio-recorded interview data were translated into English. Grounded theory techniques were used for data analysis (Corbin \& Strauss, 2008). Data analysis was conducted using multiple stages of coding, beginning with initial color coding, substantive, and theoretical coding. We identified common elements, then grouped those elements together into initial codes. We compared and contrasted each code to identify additional themes and patterns. Using analytic strategies in grounded theory that are interactive and 
comparative, we made systematic comparisons between the data sets with the intent of actively building a new theory that emerged by the end of the research process (Charmaz, 2006; Corbin $\&$ Strauss, 2008). Since the insights from the participants lie in the center of the data collection process in this study, we followed the inductive process of developing theories in order to respect and deliver the authentic voices from the participants (Bogdan \& Biklen, 2007). Through the data analysis, we identified three main themes: 1) experiences of childhood trauma during and after the refugee journey, 2) intersectional oppression of female North Korean adolescents, and 3) the construction of dis/ability and identity in school.

\section{Results}

\section{Experiences of Childhood Trauma During and After the Refugee Journey}

After leaving their home country, North Korean refugees often face a threat to their wellbeing as undocumented residents in China. Jung, a male participant at Hankook School, described his struggles related to his legal and social status as a refugee in China. After escaping from North Korea at the age of nine, Jung and his mother spent five years in China as refugees. Jung's mother was sold by traffickers and forced to live with a Chinese man. Living with his Chinese stepfather, Jung and his mother had to hide their status and identity as North Korean refugees because of fear of deportation to their homeland. Jung recalled experiencing a series of threats, abuses, and discrimination during his time in China:

I was bullied by other kids in town. Older people, like adults, also beat me up. They degraded me so badly because I was from North Korea. "This is not your country. You don't belong here. You will be deported to North Korea if we call the police. You can't do anything here."

Without legal citizenship or local language proficiency, Jung's social position had drastically changed as a refugee who had to hide his status and identity in China. Being a North Korean refugee also affected his personality and behavior. Back in North Korea, Jung reported he was the strongest and most mischievous boy in town and used to bully other kids. Jung described his shift from being a bully, to being bullied, during his time in China: 
I could've beaten them up easily, but I didn't because of my mom. I didn't care if I got arrested for beating up other kids, but I couldn't let my mom be arrested because of me. Coming home after being bullied by other kids, I would punch the wall in the house with my fist to break my bones. So, I had to restrain myself.

Even though local people living in the same village as Jung knew that Jung and his mother were North Korean refugees, they did not report their status to the Chinese authorities, because North Korean female wives were often considered "property" of Chinese men. While living in China for five years, Jung and his mother were surveilled by local people and Chinese authorities. Jung and his mother were able to escape from their village in China and safely relocate to South Korea. Jung explained that the conditions he experienced as a refugee in China led him to develop social anxiety and depression:

As I told you before, I mostly stayed at home in China. When I came to South Korea, I didn't know anything about this society. I was afraid of even going outside or being in public. I didn't know what to do and didn't have any self-esteem. And because of the stress and resentment that I had in China, I had a phobia of interacting with people and finally got depression.

In South Korea, Jung became afraid of interacting with people in public, such as in a subway or supermarket, because of his unfamiliarity with South Korean society and the pressure to hide his identity that he experienced in China.

Shane, a male participant and member of United Korea, crossed the border at the age of nine with his sister. However, he and his sister were deported back to North Korea because their refugee status was revealed while in China. Shane recalled the day that he and his sister were caught by the Chinese authorities:

My father escaped North Korea and moved to South Korea a couple years before us. Then, he contacted us [Shane and his older sister] to bring us to South Korea. He sent us a smuggler who helped us cross the border. One day in China, we took a bus to move to another country, but then one Chinese guy asked the man who led us [smuggler] to borrow his phone. He kept talking to someone on the phone. It turned out that he was 
suspicious of us for not talking to each other at all on the bus. So, he called the Chinese police to report that we seemed like North Korean refugees.

Since Shane and his sister could not speak Chinese, they did not speak to each other in public; otherwise their North Korean status would be revealed. For North Korean refugees, the ability to speak the Chinese language is not just a means of communication but a survival strategy, because language is the most obvious determinant of identifying someone as a non-Chinese citizen. Shane and his sister were deported from China back to a deportation center in North Korea. He recalled the conditions at the deportation center:

All the people in our group got deported to North Korea. I was like nine years old at that time. Once deported, we were investigated about why we left our country at the state political security department. They sometimes hit people badly. At the detention center, my sister got a disease. Soon after my sister and I were released from the state political security department, my sister died. Since then, I didn't have any hope, but thinking about leaving my home country again.

As a young child, Shane experienced several traumatic conditions, such as being deported, harshly investigated, and witnessing the loss of his sister. In his second attempt to escape from North Korea, Shane was able to take a safer journey, due to his father's financial help. Shane reported that his father did not want to lose his only child after his daughter's death. Therefore, his father sent Shane enough money to hire several smugglers to help make his second attempt to relocate to South Korea in a safer and quicker fashion.

While Jung and Shane's experiences demonstrate how they embodied the psychological distress of their social and physical environments during their relocation to South Korea, other participants attested to the distress they encountered once in South Korea. Kim, a female participant at Hankook School, shared that after she relocated to South Korea, she experienced having a "Gonghwangjangae iiii" (panic disorder). Kim reported that her condition made it difficult to interact with people in public. She recalled, "I could not make eye contact with people. For about three months, I kept wearing a cap [to avoid making eye contact with other people]." 
Ms. Yeon, a school leader of Hankook School, also reported that several students in her school continuously deal with trauma due to the conditions that they had to endure in North Korea and throughout their refugee experience:

Because our students survived many dangerous and oppressive conditions in North Korea and China at a very young age, they have serious psychological traumas. Imagine that you are running a race. When you fall during the race, you don't feel the pain until you pass the finish line. Our students are like that. They won't get to feel how physically and mentally sick or stressed they are until they come to South Korea. Here, they finally begin to feel all these conditions.

Ms. Yeon observed that students' health conditions are often deeply rooted in the adversities that students faced during and after their refugee journey, and that they need time to recover from the conditions they have experienced. Ms. Yeon continued:

Students come to me and share their experiences, like being trafficked, physically abused, [and] facing several incidents of human rights violation which they could not stand up to as a young child. They had to endure such conditions to survive during their refugee journey. However, those experiences left sore wounds to our students already, and it often makes them experience hard time here [South Korea] ... About 30 percent of our students have had medical treatment with medications for their mental health conditions.

In response to the students' lingering physical health problems, teachers and school leaders at Hankook School prioritized providing support for students' physical and mental health by offering students free physical and mental health checkups. Based on the results of the checkups, students, including Mi, Hyang, and Young, were referred for supports such as counseling provided by the school, as well as visiting art therapists and psychiatric doctors.

Economic demands also place North Korean refugee children and adolescents in positions that make them vulnerable to acquiring physical impairments. For example, Moon, a male participant at Hankook School, spent 10 years in China as a refugee, trying to make a living while hiding his identity as a North Korean refugee. Moon left North Korea at the age of 12 with his mother. As soon as they crossed the border to China, his mother was sold to a Chinese man in 
a rural area. Initially, Moon lived with his Chinese stepfather and worked on the farm performing strenuous labor. Exhausted from the work on the farm, Moon left home to make money on his own. For ten years, Moon worked at many different places to support himself, as a construction worker and kitchen helper in a restaurant. Moon recalled the limited options he had to support himself and the effect that working had on his body:

I did so many different things to make money, ever since I left my stepfather's farm. At my age of 13 , I began to work as a construction worker building an apartment complex, for about five years. Because I couldn't go to school and couldn't learn while working there, I didn't have any skills. All I could do was just using my manual labor, which was really exhausting. It was so hard, physically...I was working to build an apartment complex, but there were not many machines to use for construction. So, we had to deliver all the heavy stuff manually. Once we start working, we were not allowed to take a break. Some days, we worked for three straight days and nights. At that time, I was so sleepy. Even though I was legally minor, other people didn't care. I had to do the same work as other [adult] workers do because we were paid as much as we worked... One day, I fell off from the construction site, like three meters high. I hurt my arm and wrist from falling. I recovered from it now, but it was very dangerous.

Without social safeguards for child labor, nor financial or medical support as a North Korean refugee, Moon experienced exhaustion and injury.

\section{Intersectional Oppression of Female North Korean Adolescents}

Female North Korean refugees are targeted for trafficking when crossing the border into China and are especially vulnerable if they cannot afford to hire a smuggler to assist in discretely crossing the border to China. They are then sold to work in the sex industry or forced to live with local men in China who purchase the women from traffickers (Choe, 2018; Hwang, 2019; United States Department of State, 2018). Young female North Koreans who are under the age of 18 are not exempt from trafficking. Eun, a female participant and member of United Korea, described having an unstable family background. She was not able to attend school in North Korea and was abandoned by her divorced parents. Eun decided to leave North Korea at age 16, yearning to have a better life in China. However, as soon as she crossed the border, she was caught by traffickers and sold to a local Chinese man: 
I didn't know that I was going to be trafficked. I was even sold three times. At first, I was sold to a very poor man who was living in the middle of nowhere. I didn't even know where I was sold because I couldn't understand any Chinese language. I didn't know what he [the man that she was sold to] was doing. I was only 16 years old at that time. About a week after I got sold to the first man, I ran away. But soon after I ran away, I got caught by another trafficker. I knew that I was going to be sold to another man by this trafficker, but I couldn't do anything because I didn't have any money and didn't speak Chinese. If I was caught by Chinese police, then I will be sent back to North Korea. Then, my life is done. I didn't have any option but following the trafficker. I was sold to another man, then I ran away my second time. Then, I got caught again, and finally sold to a man who lived in Shenyang. This guy had a disability but his family was rich. He was about 24 years old but his mental age was like seven years old. He couldn't speak and potty himself. His parents bought me to take care of their disabled son. I was there for about 2 years and locked inside the house so that I couldn't run away. I could not go outside for about 1 year.

After a third attempt to escape from the Chinese family to which she was sold, Eun was rescued by a member of a non-governmental organization working in China to help North Korean refugees safely relocate to South Korea. Not knowing anyone in South Korea and feeling lonely, Eun reported that she began experiencing depression after she relocated to South Korea, and did not leave her home to interact with others for three months.

While living in China for years with little access to medical care, some female refugees develop gynecological issues. Mr. Song, a teacher working at Hankook School, explained the supports provided to female students who were trafficked while in China:

Several female students in our school experienced childbirth or something related to that in China. So, some students are found to have sexually transmitted diseases (STD), which they didn't even know. When it is discovered from a health checkup, we help them to receive proper treatment. It is quite difficult to talk to students when they were found to have STD. In that case, female teachers usually accompany the student to the hospital for treatment. 
Mi, a female participant at Hankook School, was also trafficked as a teenage girl in China. Mi was a young mother who gave birth to a child of a man whom she was sold to in China. She decided to leave her child behind and escape to South Korea. Mi expressed struggling with the feeling of guilt for giving up her child and yearning to have a presence in her child's life. Mi experienced serious depression and, shortly after arriving in South Korea, attempted suicide. Mi had to be hospitalized until she was physically and emotionally recovered from the suicide attempt.

Although school-age female North Koreans are often in need of medical and emotional support by the time they arrive in South Korea, many of them feel reluctant to ask for help due to the negative judgments imposed upon their identity and backgrounds. As the number of North Korean refugees has increased in South Korea, the dangerous journey that many North Korean refugees undergo (e.g., trafficking or deportation) has been increasingly publicized. However, the public often stigmatizes female North Korean refugees, as they are often viewed as scapegoats of sex trafficking, or even as sex workers who traded their virginity as a means of survival during their refugee journey (Lee, 2011). The stigmatized identity of being both female and a North Korean refugee leads individuals to encounter further marginalization, even after relocating to South Korea.

\section{The Construction of Dis/ability and Identity in School}

Another prominent component of participants' experience was how their academic performance and identity were constructed in relation to multiple educational contexts before, during, and after their journey of relocation. All the North Korean refugees in this study reported that they had interrupted short- or long-term formal education during, and sometimes before, their time as refugees and even in North Korea for various reasons. Hyang, a female participant at Hankook School, had to discontinue her elementary education in North Korea because of the economic hardship she faced after her father's passing. In North Korea, the government claims to guarantee 12 years of free compulsory education to North Korean students from kindergarten to high school (KINU, 2018). However, since a nationwide famine, the government failed to provide free public education; therefore, students were required to provide goods (e.g., rabbit skins, rice, or iron) to their school regularly, in lieu of monetary tuition (KINU, 2019). These non-monetary goods were collected and distributed to teachers who do not earn a living wage from the government. Because Hyang could not provide non-monetary goods after her father 
passed away, she could not attend elementary school. Instead, Hyang had to work for several of her mother's different boyfriends who occasionally abused Hyang. Hyang described her daily routine:

It is really dark at 5 a.m. in North Korea. Especially in the winter, it is completely dark. My step-fathers, well, I would say they were just my mom's boyfriends. Anyway, they would wake me up at 5:30 a.m. and make me deliver corn stalks to be used as food for our goats. In the summer, I had to do weeding, and in the fall, I had to do gleaning, like collecting left rice or grains in the farm. In the winter, I still had to do gleaning and deliver charcoals.

Having dealt with economic hardship for a few years after her father passed, Hyang and her mother finally escaped. Until Hyang and her mother relocated to South Korea, Hyang did not receive any formal education for about four years.

Several participants shared that after relocating to South Korea, they were not able to participate in classroom learning activities in mainstream schools to the same degree as their South Korean peers. They attributed this difficulty to their interrupted formal education and differences in curriculum, and/or expectations of the education system. They also reported developing a negative perception about their academic identity, including viewing themselves as underachievers or slow learners. Hyang explained how her low academic performance directly led her to undervalue her ability as a learner while attending a mainstream school:

When I attended a regular school, I couldn't understand anything that was taught. I knew nothing in English, math, or Korean history class. Especially in math class, I didn't even know if I solved the problem correctly or not. I had no confidence about myself at all as a student. Because of my low self-esteem, I stopped expressing my opinions at school. I was like an invisible person. I didn't talk to anyone at all in school.

To hide her lack of understanding of the curriculum, Hyang tried to be as unnoticeable as possible to teachers and her peers. Hyang explained that this demeanor as a student drastically changed from when she was an outgoing and high-achieving student in North Korea. 
Young, a female participant at Hankook School, who left North Korea at the age of 14, had a similar experience as Hyang. Young was not able to receive formal education for most of her childhood in North Korea as well as China. She faced a tremendous challenge within the academically competitive environment of South Korean schools:

North Korean kids are not good at anything, so to speak. In South Korea, you have to be really exceptional to be able to say that you are good at something. Because South Korean kids are way advanced in many areas, I don't have anything to say as strengths compared to them. I don't even know what I like.

Her understanding about her own identity as a student shifted drastically from the North to the South Korean educational context, where Young evaluated her academic performance in comparison to the average South Korean students that she observed in mainstream schools.

\section{Discussion and Conclusion}

The purpose of this paper was to examine the intersection of disability and refugee identity in the childhood of North Korean refugees. Using Critical Disability Studies (CDS) as a framework, the analysis focused on both embodied and sociocultural factors that constitute North Korean refugees' experiences of disability. While most of the participants were young adults, their perspectives provide insight into their childhood experiences across multiple borders and social contexts. The results demonstrate how being a refugee - both the political identity and embodied experience of relocating - permeates multiple facets of children's lives to uniquely position them to experience disability in diverse and complex ways.

The experiences of participants in this study demonstrate the structural, political, and economic conditions that deny North Korean refugees access to rights guaranteed in the Convention on the Rights of the Child. Because they are undocumented residents in China, North Korean refugees experience many of the oppressive conditions experienced by other refugees around the world, including being denied healthcare, formal education, and legal rights that would protect them from child labor (Dryden-Peterson, 2011). They also experience separation from their families, including Mi who struggled with guilt when leaving behind her child in order to escape China to reach South Korea, or Moon who left his mother after she was trafficked to avoid the abuse of the man she was forced to marry. 
These examples also reinforce existing literature of how refugee status intersects with gender, class, and disability on refugees' journeys. Similar to the experiences of Cambodian and Somalian refugees studied by Mirza (2011), financial resources and disability shape how, if, and when North Koreans are able to successfully relocate to South Korea. The financial resources to access smugglers can provide a comparatively safer journey and protection from disabling conditions, as was the case for Shane. As with other female refugee groups (United States Department of State, 2018), female North Korean refugees, such as Eun, Mi, and the mothers of Jung and Moon, were particularly vulnerable to abuse as they were targeted by traffickers in China. Such oppressive physical conditions become mapped onto their psychological characteristics. Several participants attested to experiencing stress, depression, anxiety, and exhaustion, illustrating the interconnected bodymind experience of trauma (Price, 2015).

However, the findings of this study also elucidate how the impact of rights, even when they are formally provided, are mediated by social dynamics. On the one hand, North Korean refugees receive significant individual rights when arriving in South Korea, including citizenship, access to healthcare, legal safeguards, and access to formal education (Ministry of Unification, 2018). As teachers and students at the Hankook school shared, students take advantage of access to healthcare, including therapy to address depression, and gynecological care. The importance of healthcare was also evident in the several references to psycho-medical discourse by student participants (i.e., naming disorders and discussing treatment).

[Yet] [On the other hand], despite relocating to a country whose government confers significant rights at the individual level, North Korean refugees also encounter marginalizing social dynamics. The highly competitive culture of schooling and lack of preparation of teachers to support North Koreans contribute to constructing North Korean refugee children as deficient versions of their native peers (Annamma, Connor, \& Ferri, 2016). Such constructions led students to develop stress, anxiety, and low academic self-esteem. Further, social isolation experienced by participants contributed to depression. Such results cannot only be explained as a continued manifestation of prior trauma. Rather, from the perspective of social embodiment, both experiences, denial of rights in China and the culture of South Korean society, become mapped onto the bodymind of refugees (Connell, 2011).

Collectively, these results underscore the importance of working to ensure that children are not denied essential rights of the Convention on the Rights of the Child, including healthcare, education, and protection from abuse, while also critically examining practices that deny the 
rights of children to enact their rights by fully participating in society (UN General Assembly, 1989). For refugees, the degree of social and cultural participation is often reflected in their inclusion in mainstream educational systems, a belief underlying the Convention on the Rights of Persons with Disabilities (UNCRPD, 2006). Yet, as the students in this study attest to, individualized rights to education do not always facilitate full and meaningful social participation. The students who attend Hankook School are not mandated to attend an alternative school for North Korean refugees. Nominally, they have a right to attend mainstream schools. However, given the negative prior experiences they describe in mainstream schools, it is not surprising that they opt for an alternative school. North Korean refugees make a constrained choice between mainstream schools that do not respond to their learning needs, or a school that may offer more support but isolate them from their South Korean peers.

The existence of alternative schools serving North Korean refugee students obscures the need to challenge the "ablenationalism" (Snyder \& Mitchell, 2010, p.113) that occurs when, despite receiving citizenship in name, the characteristics of North Korean refugees are constructed as deficit versions of their native South Korean peers who represent the able-bodied norms of citizenship. The existence of alternative schools [alleviates] relieves mainstream schools and policy makers from the responsibility of providing responsive educational supports to North Korean refugees within the mainstream school system, and therefore from promoting an essential element of their integration into the social, cultural, and political community. Listening to the voices of refugee students demonstrates the embodied consequences of such marginalization and demands structures and practices that embrace refugees as full citizens, both in name and in spirit.

\section{Notes}

\footnotetext{
i In this paper, we adhere to the definition of refugee by the United Nations High Commissioner for Refugees (UNHCR). According to the UNHCR in 1951, refugee is defined as a person who "owing to well-founded fear of being persecuted for reasons of race, religion, nationality, membership of a particular social group or political opinion, is outside the country of his nationality and is unable or, owing to such fear, is unwilling to avail himself of the protection of that country; or who, not having a nationality and being outside the country of his former habitual residence as a result of such events, is unable or, owing to such fear, is unwilling to return to it" (UNHCR, 2018b, p.14).

ii Upon arriving in South Korea, all North Koreans are given South Korean citizenship. Therefore, they no longer have refugee status.

iii In this paper, we used the Revised Romanization system when inserting Korean terms.
} 


\section{References}

Aldrich, R. (2011). An examination of China's treatment of North Korean asylum seekers. North Korean Review, 7(1), 36-48.

Annamma, S. A., Connor, D., \& Ferri, B. (2016). Dis/ability critical race studies (DisCrit): Theorizing at the intersections of race and dis/ability. In D.J. Connor, B.A. Ferri, \& S.A. Annamma (Eds.), DisCrit: Disability studies and critical race theory in education (pp. 932). NY: Teachers College Press.

Bogdan, R., \& Biklen, S. K. (2007). Qualitative research for education: An introduction to theories and methods. Boston, MA: Pearson A \& B.

Charmaz, K. (2006). Constructing grounded theory: A practical guide through qualitative analysis. London, UK: SAGE.

Choe, S-H. (2018, November 25). Children of North Korean mothers find more hardship in the south. The New York Times. Retrieved from https://www.nytimes.com/2018/11/25/world/asia/north-korean-childrendefectors.html?searchResultPosition=1

Choi, S. (2011). Ethnic brethren and the national 'other': North Korean refugee youth in South Korea. Oxford Monitor of Forced Migration, 1(2), 51-57.

Connell, R. (2011). Southern bodies and disability: Re-thinking concepts. Third World Quarterly, 32(8), 1369-1381.

Corbin, J. \& Strauss, A. (2008). Basics of qualitative research (3rd ed.): Techniques and procedures for developing grounded theory. Thousand Oaks, CA: SAGE Publications.

Crenshaw, K. (1989). Demarginalizing the intersection of race and sex: A black feminist critique of antidiscrimination doctrine, feminist theory and antiracist politics. $u$. Chi. Legalf., 139.

Dryden-Peterson, S. (2011). Refugee education: A global review. Geneva: UNHCR.

Erevelles, N. (2011). Disability and difference in global contexts: Enabling a transformative body politic. New York, NY: Palgrave Macmillan.

Fazel, M., Reed, R. V., Panter-Brick, C., \& Stein, A. (2012). Mental health of displaced and refugee children resettled in high-income countries: Risk and protective factors. The Lancet, 379(9812), 266-282. 
Garland-Thomson, R. (2005). Feminist disability studies. Signs: Journal of Women in Culture and Society, 30(2), 1557-1587.

Garland-Thompson, R. (2011). Misfits: A feminist materialist disability concept. Hypatia: A Journal of Feminist Philosophy, 26(3), 591-609.

Graham, H. R., Minhas, R. S., \& Paxton, G. (2016). Learning problems in children of refugee background: A systematic review. Pediatrics, 137(6), e20153994.

Goodley, D. (2013). Dis/entangling critical disability studies. Disability \& Society, 28(5), 631644.

Hacking, I. (1999). The social construction of what? Cambridge, MA: Harvard University Press.

Harlan, C. (2012, February 15). North Korean defectors learn quickly how to send money back home. The Washington Post. Retrieved from https://www.washingtonpost.com/blogs/blogpost/post/north-korean-defectors-learnquickly-how-to-send-money-backhome/2012/02/06/gIQAgsEeFR_blog.html?noredirect=on

Human Rights Watch. (2018, November 1). North Korea: Sexual violence against women by officials: Impunity for assault and rape by men in power. Human Rights Watch. Retrieved from https://www.hrw.org/news/2018/11/01/north-korea-sexual-violence-againstwomen-officials

Human Rights Watch. (2019). World report 2019: North Korea events of 2018. Human Rights Watch. Retrieved from https://www.hrw.org/world-report/2019/country-chapters/northkorea

Hwang, S-M. (2019, January 18). The North Korean women who had to escape twice. $B B C$ News. Retrieved from https://www.bbc.com/news/world-asia-46610882

Korean Educational Development Institute (KEDI). (2016). Statistics of education for North Korean refugee students. Retrieved from http://www.hub4u.or.kr/hub/edu/status01.do

Korea Institute for National Unification [KINU] (2017). White paper on human rights in North Korea: 2017. Seoul: KINU.

Korea Institute for National Unification [KINU] (2018). White paper on human rights in North Korea: 2018. Seoul: KINU.

Korea Institute for National Unification [KINU] (2019). White paper on human rights in North Korea: 2019. Seoul: KINU. 
Lankov, A. (2011, April 10). Remittances by defectors. The Korea Times. Retrieved from http://www.koreatimes.co.kr/www/news/opinon/2011/04/137_84916.html

Lee, K. (2006). The border-crossing North Koreans: Current situations and future prospects. Seoul, Korea: Korea Institute for National Unification (KINU).

Martin, D. C., \& Yankay, J. E. (2014). Refugees and asylees: 2013. East Asia, $16(18,000)$, 19000.

Meekosha, H., \& Shuttleworth, R. (2009). What's so 'critical' about critical disability studies? Australian Journal of Human Rights, 15(1), 47-75.

Ministry of Unification (2019). Data and statistics: Policy on North Korean defectors. Ministry of Unification. Retrieved from https://www.unikorea.go.kr/eng_unikorea/relations/statistics/defectors/

Mirza, M. (2011). Disability and cross-border mobility: Comparing resettlement experiences of Cambodian and Somali refugees with disabilities. Disability \& Society, 26(5), 521-535.

OECD. (2019). Unemployment rate. doi: 10.1787/997c8750-en Retrieved from https://data.oecd.org/unemp/unemployment-rate.htm

Pisani, M., \& Grech, S. (2015). Disability and forced migration: Critical intersectionality. Disability and the Global South, 2(1), 421-441.

Price, M. (2015). The bodymind problem and the possibilities of pain. Hypatia, 30(1), 268-284.

Schwartzman, N. (2009, June 5). Alternative school is first with principal from North Korea. Asian Correspondent.com. Retrieved from https://asiancorrespondent.com/2009/06/alternative-school-is-first-with-principal-fromnorth-korea/

Shakespeare, T. (2014). Disability rights and wrongs revisited. New York, NY: Routledge.

Snyder, S., \& Mitchell, D. (2010). Introduction: Ablenationalism and the geo-politics of disability. Journal of Literary \& Cultural Disability Studies, 4(2), 113-125.

Soldatic, K., \& Grech, S. (2014). Transnationalising disability studies: Rights, justice and impairment. Disability Studies Quarterly, 34(2).

Thomas, C. (2004). How is disability understood? An examination of sociological approaches. Disability \& society, 19(6), 569-583. 
United Nations Convention on the Rights of Persons with Disabilities [UNCRPD]. (2006).

Convention on the rights of persons with disabilities. United Nations. Retrieved from http://www.un.org/disabilities/convention/conventionfull.shtml

United Nations High Commissioner for Refugees [UNHCR]. (2018a). World at war: UNHCR global trends: forced displacement in 2018. Geneva: UNHCR.

United Nations High Commissioner for Refugees [UNHCR]. (2018b). Convention and protocol relating to the status of refugees. Geneva: UNHCR.

UN General Assembly. (1989). Convention on the Rights of the Child. United Nations, United Nations, Treaty Series, 1577(3).

United States Department of State. (2018). Trafficking in persons report: June 2018.

Washington, D.C.: Office of the Under Secretary for Civilian Security, Democracy, and Human Rights.

\section{Korean Sources}

Jung, J-K., Jung, B-H., \& Yang, K-M. (2006). The adjustment of North Korean refugee youths to South Korean schools. Journal of Korean Psychological Association. 2006(6), 362-363. 정진경, 정병호, 양계민 (2006). 탈북 청소년의 남한학교 적응. 한국심리학회 학술대회 자료집.

Lee, H-J. (2011). The structural abuses of human rights and coping methods that women defectors from North Korea: Focusing on relationships with the opposite sex in emigrant experience. Peace Studies, 19(2), 367-404. 이화진 (2011). 탈북여성의 이성 관계를 통해본 인권침해 구조와 대응 탈북 및 정착과정을 중심으로. 평화연구.

Ministry of Unification (2018). 2018 Handbook of resettlement support for North Korean defectors. Seoul, South Korea: Ministry of Unification. 통일부 (2018). 2018 북한이탈주민 정착지원 실무편람. 통일부.

Yoo, J-W. (2008). Social exclusion of North Korean defectors. The Korean Journal of Unification Affairs, 47(32), 145-175. 유지웅 (2008). 북한이탈주민의 사회적 배제. 통일문제연구.

Kim, Y-H. (2010). A path analysis of factors influencing the school drop-out intentions of North Korean defector youth. Studies on Korean Youth, 21(1) 33-65. 김연 희(2010). 북한이탈청소년의 학교중도탈락 영향의 경로구조 연구. 한국청소년연구. 